مطالعه آزمايشگاهى اثر ديوارههاى روزنهدار در حوضجه آرامش بر عمق ثانويه و طول غلتاب برش هيدروليكى

\author{
رضا خانخانى زوراب" و سيد محمود كاشفى يور'
}

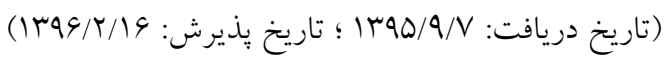

جكيده

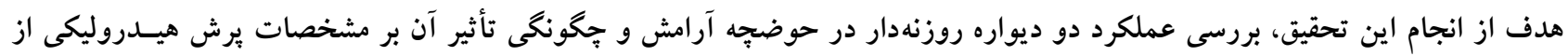

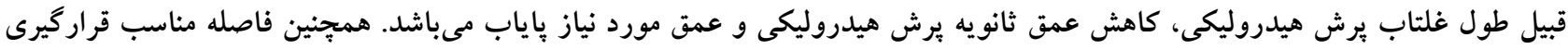

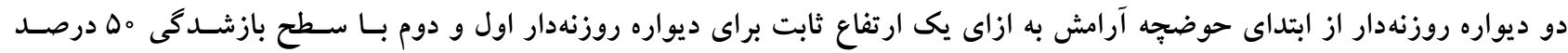

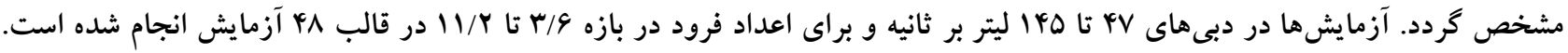

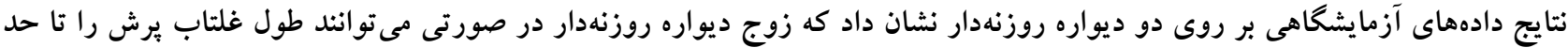

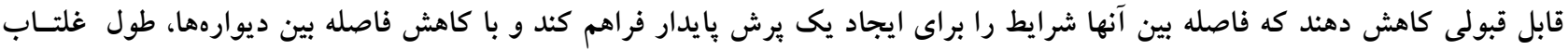

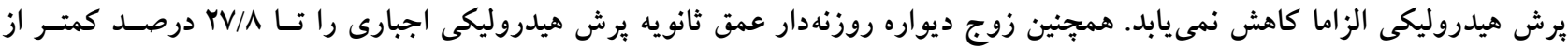

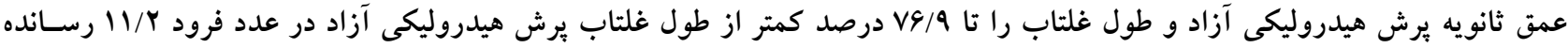

وازههاى كليدى: ديواره روزنهدار، برش هيدروليكى، حوضجه آرامش، طول غلتاب، عمق ثانويه برش اجبارى

\footnotetext{
ا. كروه سازههاى آبى، دانشكده مهندسى علوم آب، دانشكاه شهيد جِمران اهواز

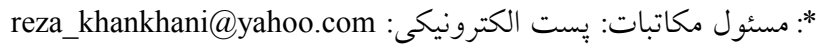




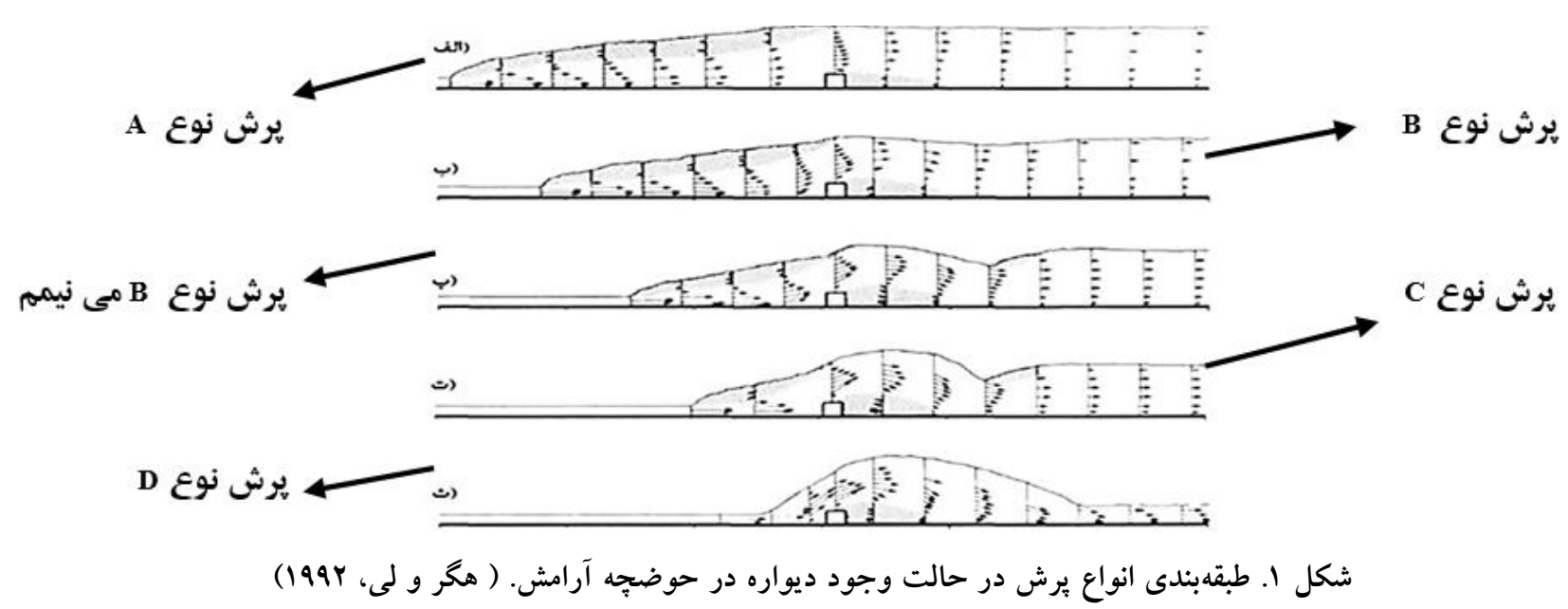

ديوارههاى دندانهدار برداخت و نتيجـهـ كرفـت كـه ديـوارههـاى

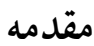

ممتد نسبت به ديوارههاى دندانهدار افت انـرزى بيشـترى ايجـاد

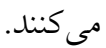

اتوسو و همكاران (91) جريان عبورى از روى ديواره را به سـه

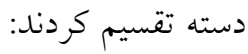

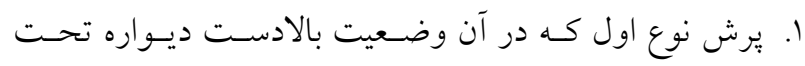
تأثير عمق باياب است.

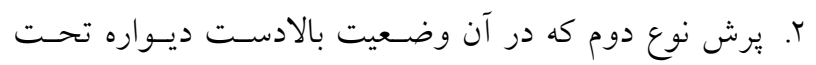

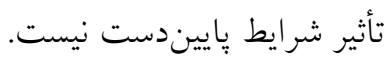

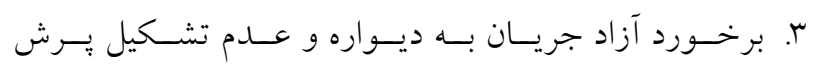
هيدروليكى در بالادست است.

مطالعات بعدى برروى برش هيدروليكى اجبارى در اثـر وجـود

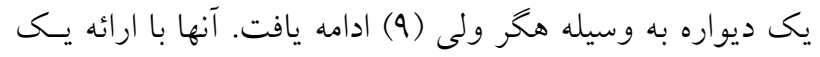

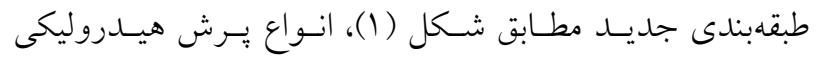

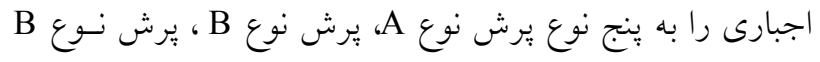

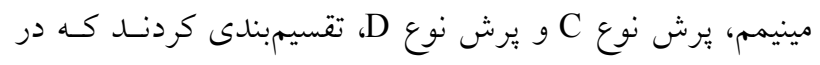

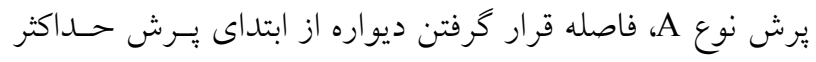
و در يرش نوعD اين فاصله حداقل مىباشد.

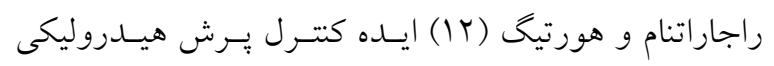

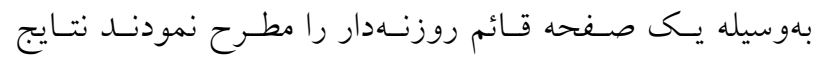

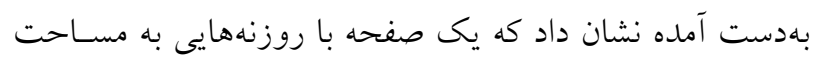

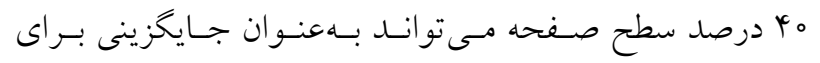

كترل يرش هيدروليكى به روشهاى مختلفى از جملـه: سـرريز

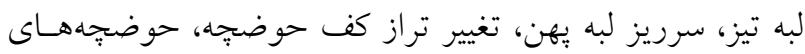

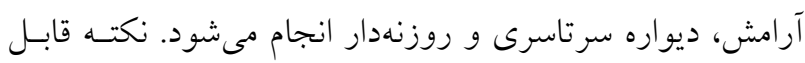

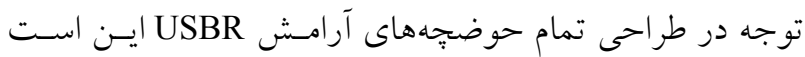
كه كف حوضجه بايستى به اندازه كافى پايين برده شود تا عمـق لق

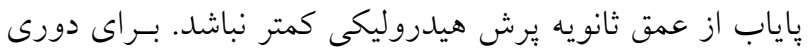

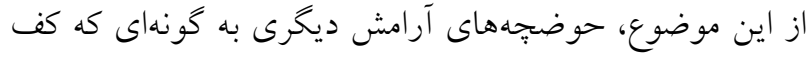

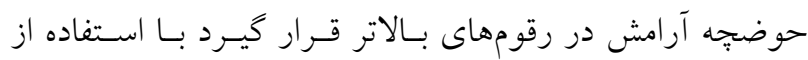

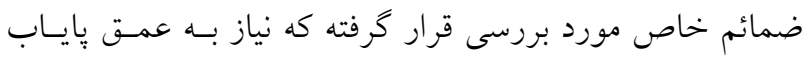

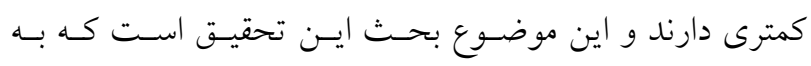

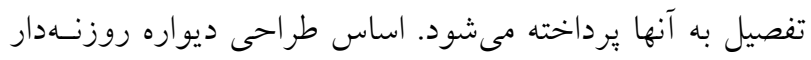

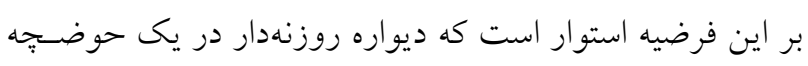

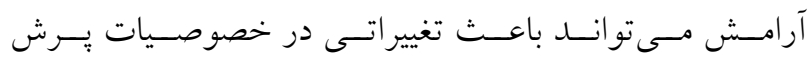

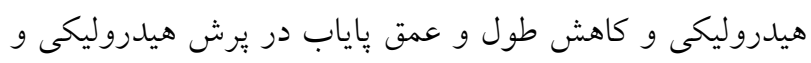
افزايش افت انرزى در يرش شود.

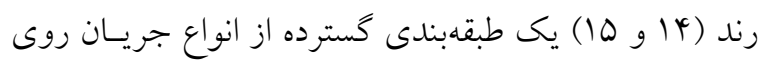

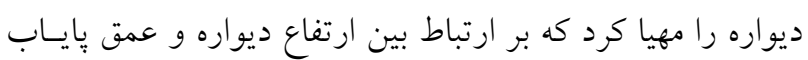

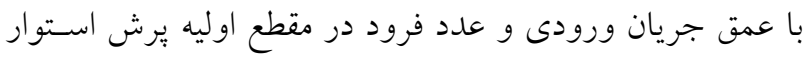

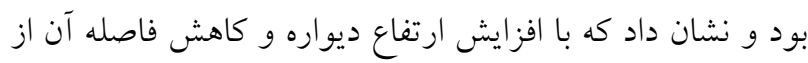

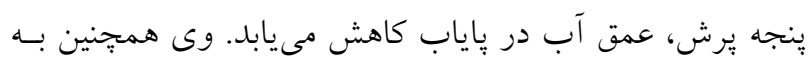

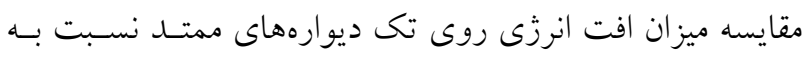


در خلاف جهت جريان تا F/D/D درصد افت نسبى انرزى نسبت به يرش آزاد را ايجاد مى كند.

اولين تحقيق اصولى درباره طول غلتابى توسط سافرانز (10) انجام شد. وى در مجموع انجام شانزده آزمايش، طـول بـىبعـد غلتابى را براى اعداد فرود بزرگتر از سو/ T/ستخراج كرد. هخر و همكاران (N) آزمايشهايى جهت تعيين طول غلتابى

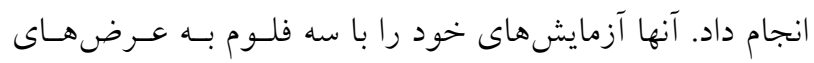

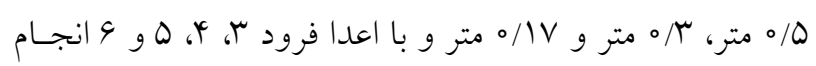
داد و دريافت كه براى >> رابطه زير بهدست مى آيد. $\lambda_{\mathrm{r}}=\mathrm{a}_{\mathrm{o}}+\mathrm{a}_{1} \omega$

كه در آن a هدف از انجام مطالعه حاضر كـاهش طـول غلتـاب و عمـق ثانويه يرش هيدروليكى بــا اسـففاده از دو ديسواره روزنسهدار بــه ارتفاع Vو سا سانتىمتر، با روزنههاى دايرهاى شكل و با درصد

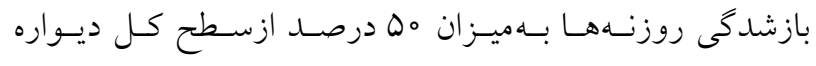
مىباشد. اكرجهه تحقيقاتى بـرروى تـى ديـواره و صـفحههـاى روزنهدار انجام گرفته، اما تاكنون تحقيقى برروى اثـر دو ديسواره روزنهدار بر مشخصات برش هيدروليكى انجام نشده است.

\section{عمقهاى مزدوج در برش هيدروليكى}

$$
\frac{\mathrm{y}_{r}}{\mathrm{y}_{1}}=\frac{1}{r}\left(\sqrt{1+\wedge \mathrm{Fr}_{1}^{r}}-1\right)
$$

رابطه (r) كه به رابطه بلانجر (Belanger) معروف است، رابطـه

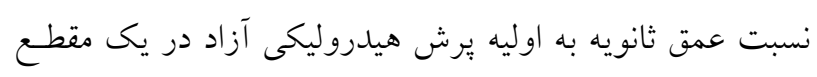

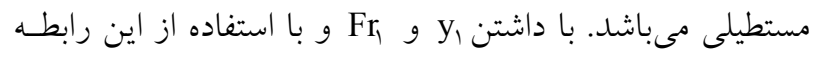
مىتوان عمق ثانويه يرش هيــرووليكى را محاسـبه نمـود. بـراى

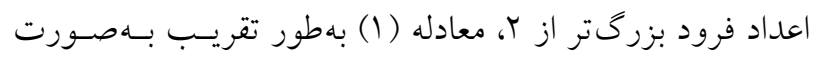
معادله بانوشته مىشود (جاو، V).

$\frac{\mathrm{y}_{r}}{\mathrm{y}_{1}}=\sqrt{\mathrm{r}} \mathrm{Fr}_{1}-\frac{1}{r}$

اين معادله نشان مىدهد كه نسبت اعماق مـزدوج
بلوكها يا ساير ضـمائم موجـود در حوضسجههــاى آرامسش در سازههاى هيدروليكى كوجى قرار گيرد. در باييندسـت صـفحه نيز جريان همجينان فوق بحرانى است ولى عدد فرود در حسدود 1/90 اكنترل مىشود. تحقيقات بعدى برروى حوضيجه هاى آرامش با يـكى ديـواره سرتاسرى بلهوسيله بيرامى و ايلاقى (1) ادامه يافت. آنها با انجام يكسرى آزمايشها نشان دادند كه با افـزايش ارتفـاع ديـواره و

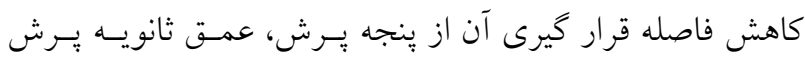

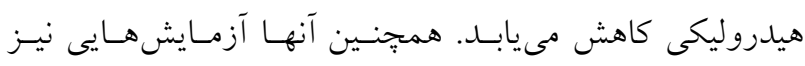
برروى كنترل يرش هيدروليكى با استفاده از دو ديسواره بيوسـته انجام داده و دريافتند كه قرارگيرى ديواره دوم بعد از ديواره اول تنها در شرايطى مىتواند در كاهش عمق ثانويه و افـزايش افـت انرزى نسبت به حالت يك ديواره مؤثر واقع شود كه ديواره دوم بلندتر از ديواره اول باشد. هلال و همكاران (0 (1) نيز به بررسى روشهـيى جهـت بـهـ

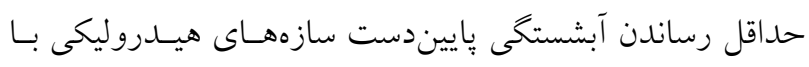

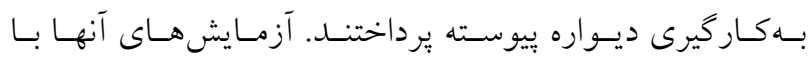
به كارگيرى آرايشهاى مختلف از ديوارههاى بيوسـته بـا ارتفــاع

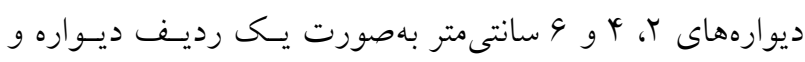
جند رديف ديواره تعبيه شده در كف يك فلوم آزمايشخاهى بـه

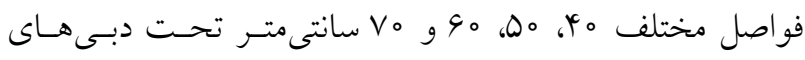
مختلف انجام بذذيرفت. آزمايشها نشـان داد كـهـ وجـود ديـواره بيوسته تـأثير قابـل ملاحظـهاى در افـزايش اسـتهلاكى انـرزى و كاهش عمق آبشستخى در ياييندست دارد. بهروزىراد و همكـاران (9) بـهـ بررسسى شـرايط جريـان بـا وجود ديواره روزنهدار يرداختند. نتايج آزمايشهـاى آنهـا نشـان داد وجود ديواره روزنه دار با درصد بازشدگى هه درصـد طـول

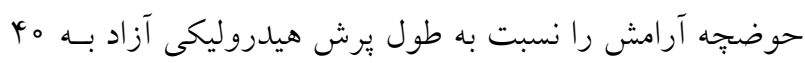
درصد مىرساند. آزمايشهاى عاشور و همكاران (Y) برروى اشكال مختلفىى از ديوارههاى منحنى شكل بيوسته با مقطع مثلثـى نشـان داد كـهـ قرارگيرى سه رديف ديواره منحنى با انحناى هبا درجه و تقعر 


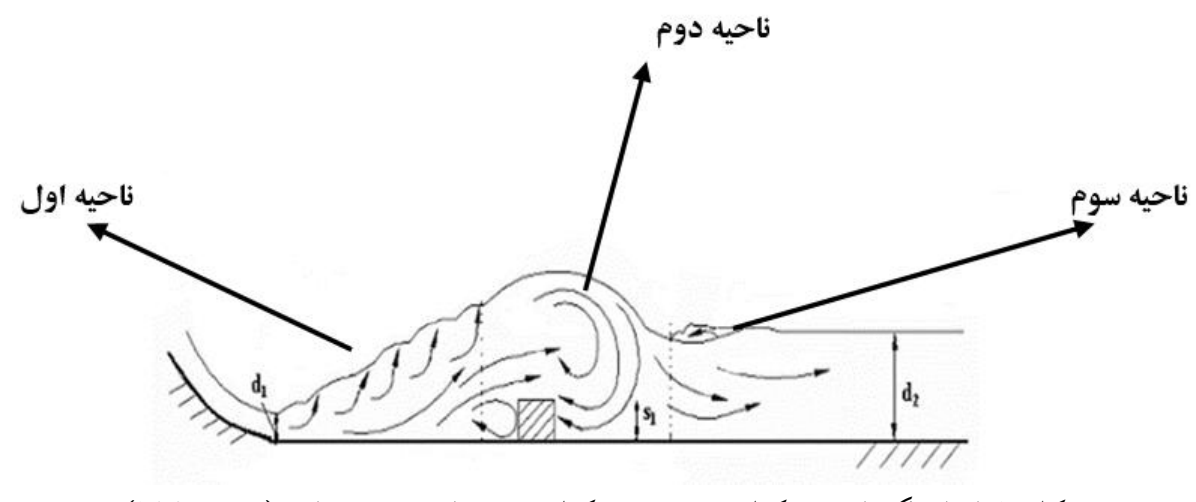

شكل r. انواع گرداب تشكيل شده در تشكيل برش با وجود ديواره (رند، 1990)

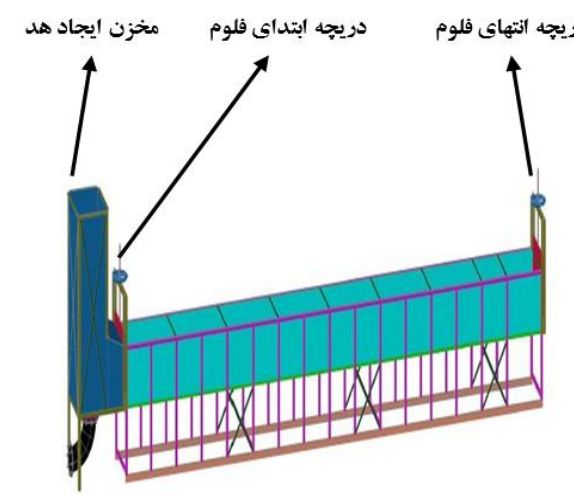

(ب)

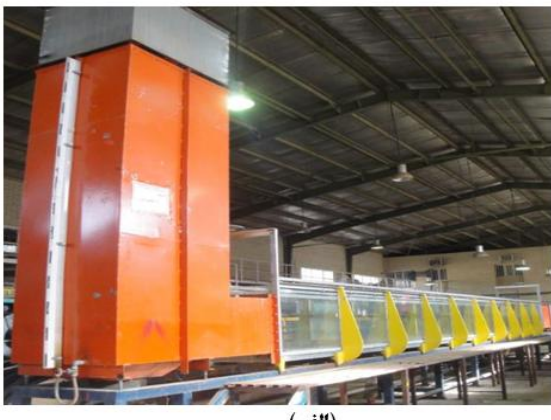

(الف)

شكل r. (الف) نماى كلى از فلوم آزمايشگاهى (ب) شماتيك فلوم

r) كردابهاى تشكيل شده در يشت ديواره

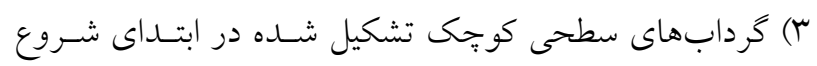

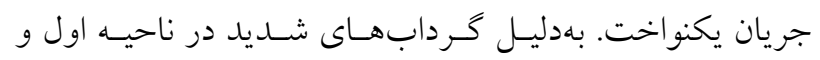

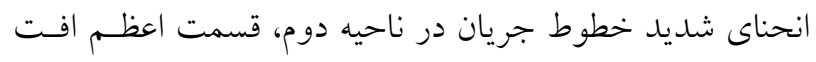

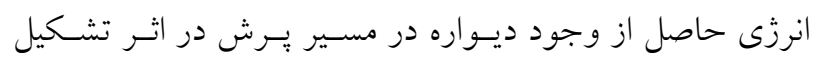

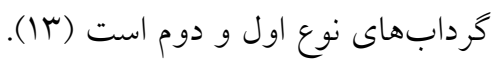

\section{مواد و روشها}

آزمايشهــاى انجـام شـــه در ايـن تحقيـق بــر روى دو ديـواره

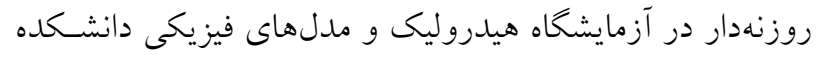

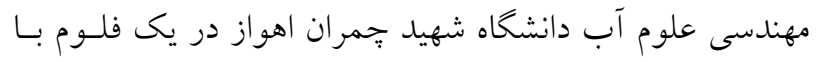
جدارهاى از جنس يلكسى كلاس و مخزن آهنس كـه در شـكل

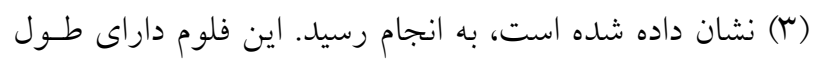

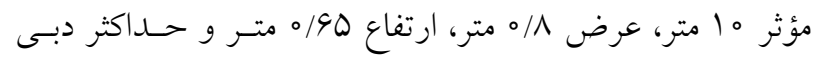

فرود بلصورت خطى تغيير مى كند.

$$
\text { طول غلتاب برش هيدروليكى }
$$

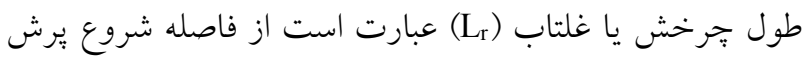
تا آخرين موج غلطان. طول بى بعد غلتابى توسط يكى از از اعماق

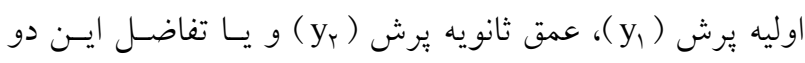

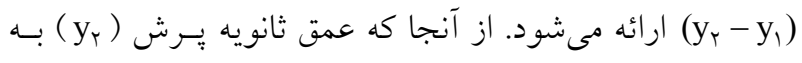

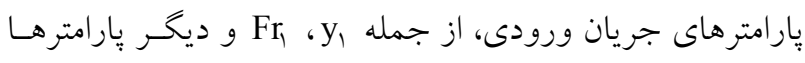

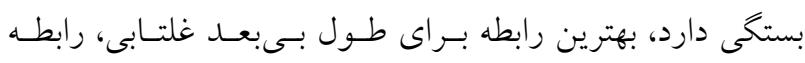
( مى ( $\left.\frac{\mathrm{Lr}}{y_{1}}\right)$

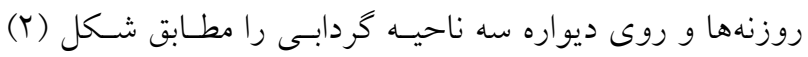
مىتوان مشاهده كرد: () گردابهاى تشكيل شده قبل از ديواره 
مهره در بشت دريجه نصب گرديد. همجنين بـراى جلـو گيرى از

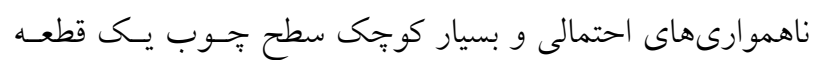

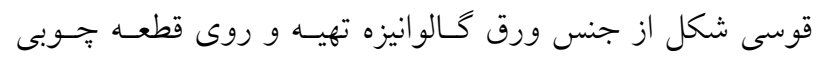

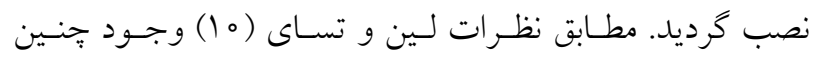

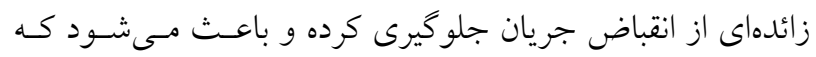

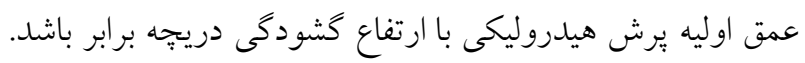

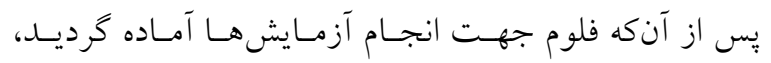

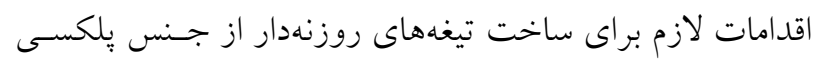

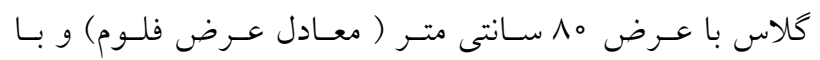

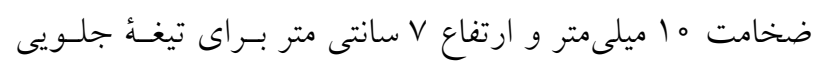
(تيغـــه اول، س/ T/ انجام كرفت. اين ارتفاعات از ديوارههـا براسـاس $\left(\frac{S_{Y}}{y_{Y}}=r / r\right)$ نتايج آزمايشهـايى بــرورى ارتفـاع بهينـه دو ديـواره روزنسهدار

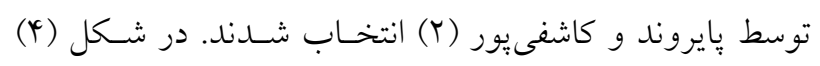

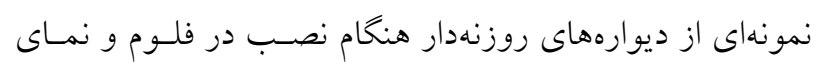

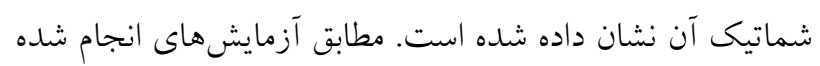

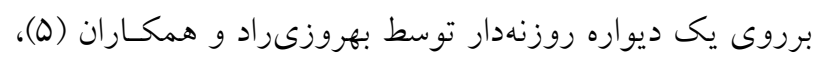

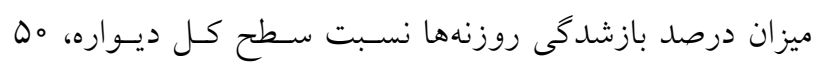

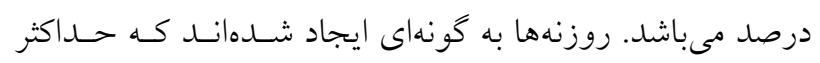

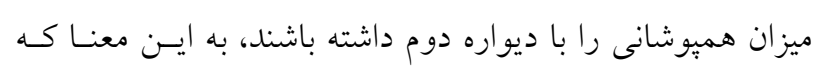
روزنههاى ديواره اول در مقابل قسمت بييوسته ديواره دوم قـرار كرفته باشند. - موزنهاي

\section{شرح اجراى آزمايشها}

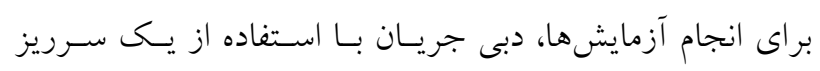

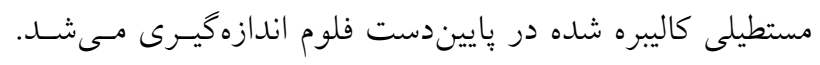

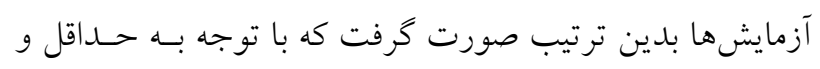

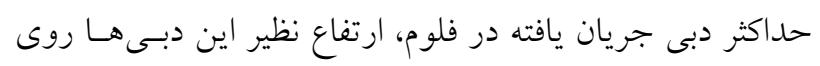

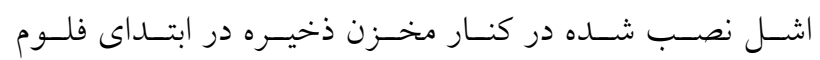

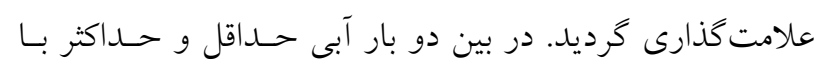

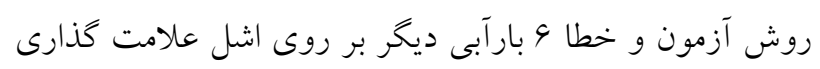

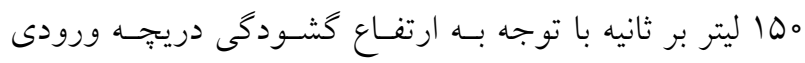
(معادل ب سانتىمتر) مىباشد.

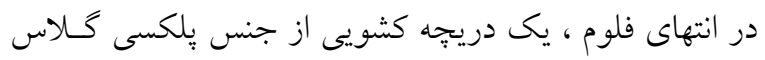

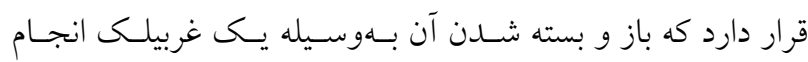

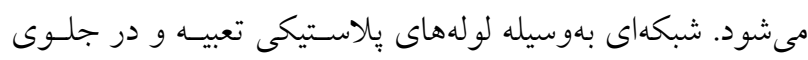

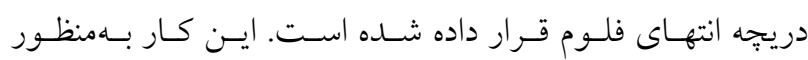

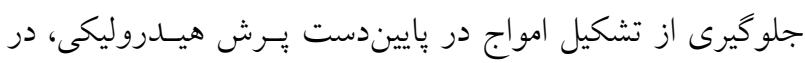
عمق باياب مىباشد. يكى سرريز مستطيلى در انتهـاى فلـوم قـرار

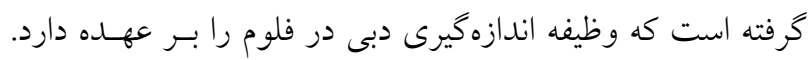

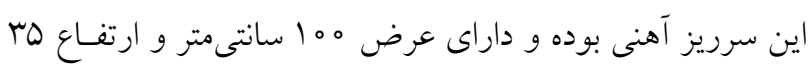

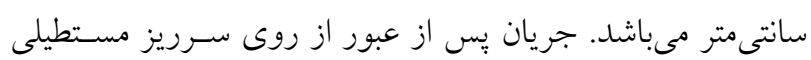

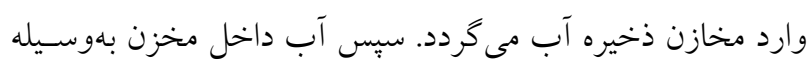

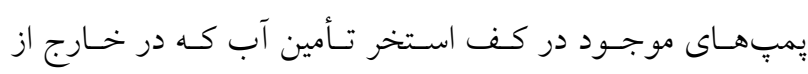

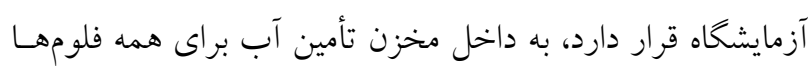

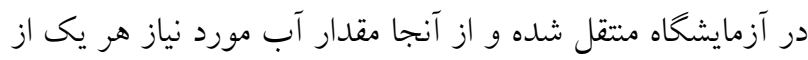

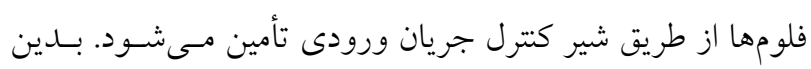
ترتيب سيستم جرخش آب در فلوم تكميل مى شيود. عمق جريـان

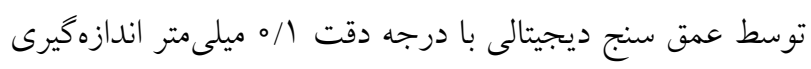

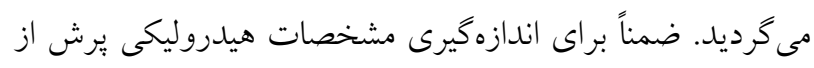

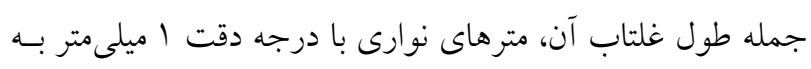

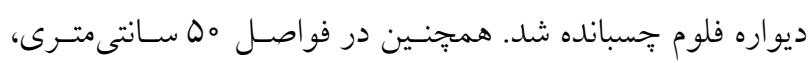

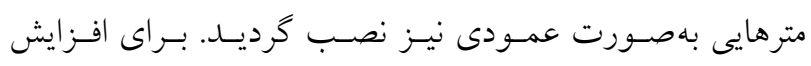

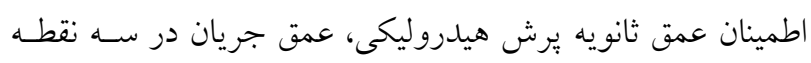
ثابت در عرض فلوم (يكى در خط مركزى فلوم و دو اندازهذيـرى

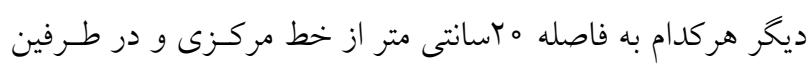

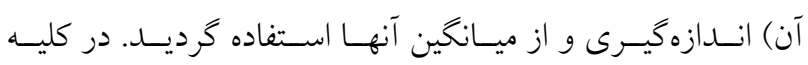

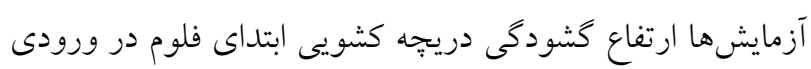

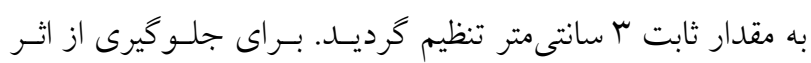
انقباض دريجه برروى عمق اوليه يرش هيدروليكى، يك قطعـه از

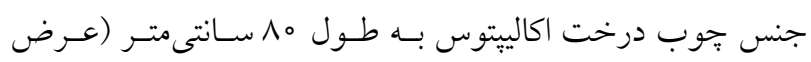

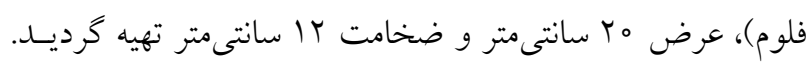

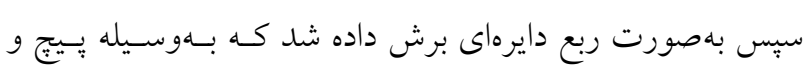



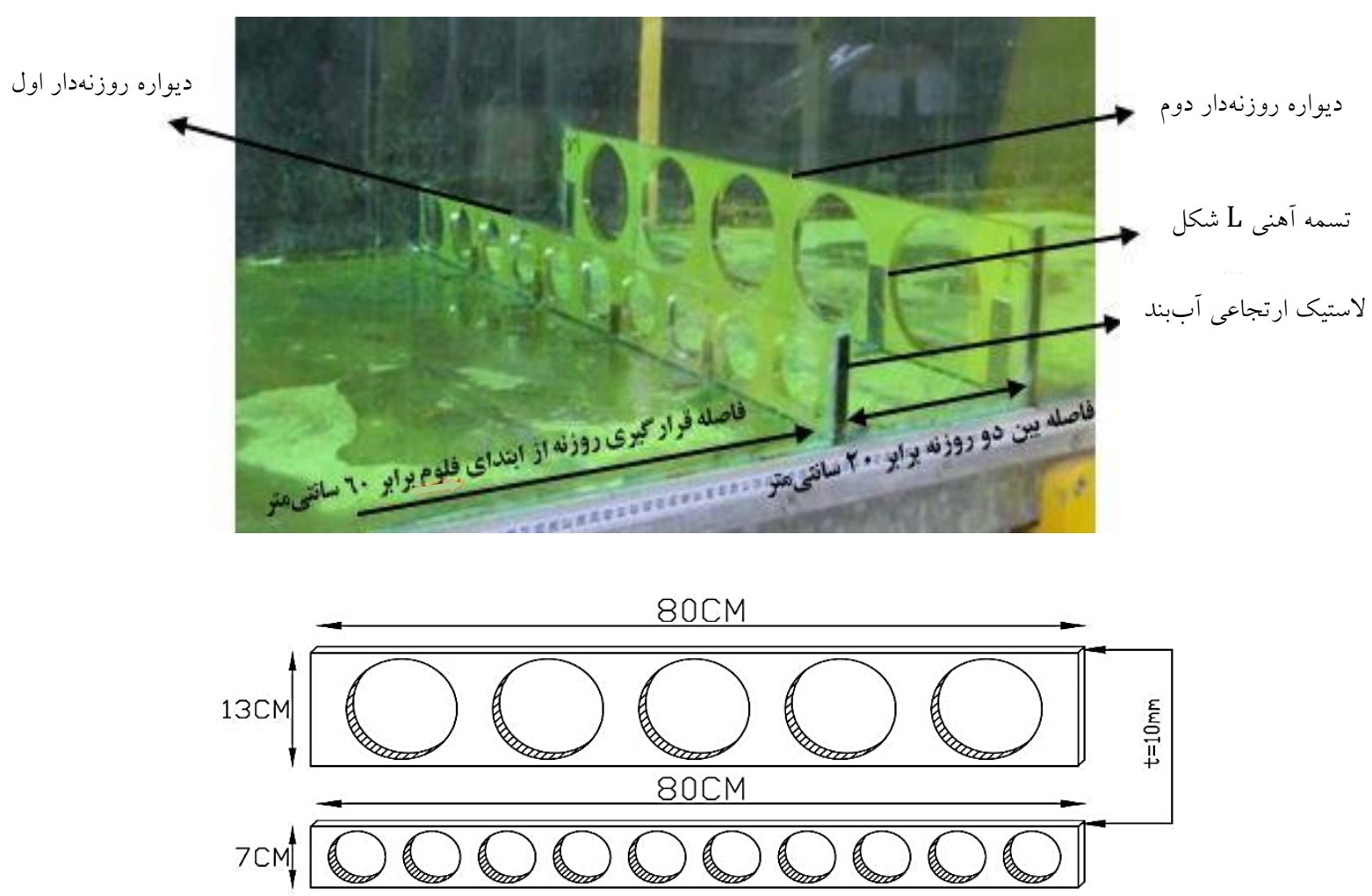

(ب)

شكل F. الف) نحوه قرارگيرى ديوارههاى روزنهدار در فلوم و ب) شماتيك ديوارههاى روزنهار

از جمله عمق ثانويه يـــ هيــروليكى و عمـق اوليـه، توسط

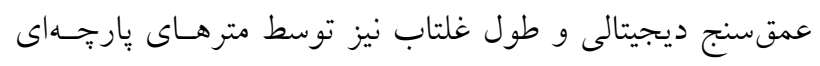

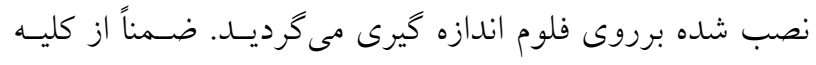

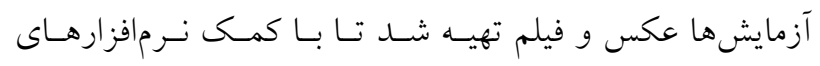

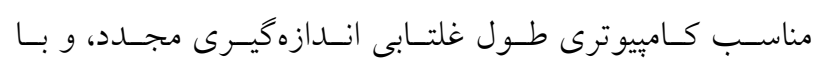

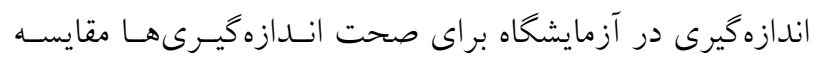

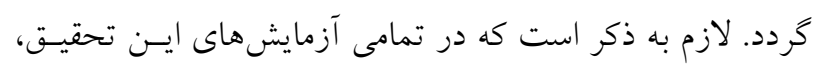

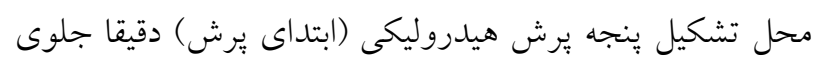

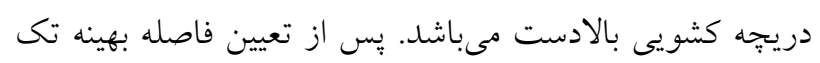

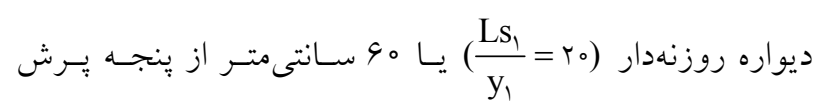
هيدروليكى) مطابق نتايج آزمايشهاى خانخـانى و كاشـفىيـور،

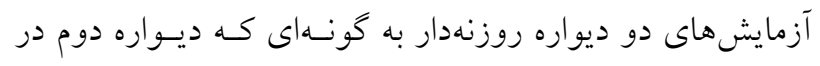
r. سانتى مترى از ديواره اول قرار كرفتـه باشــ، $\left(\frac{\mathrm{Ls}_{Y}-L s_{1}}{y_{1}}=10\right)$
كَرديد تا با توجه به دبىهايى كـه از منحنسى دبسى اثـل سـرريز

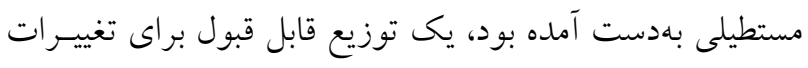

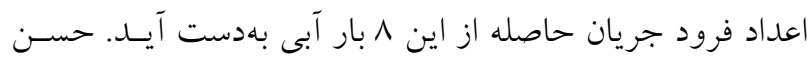

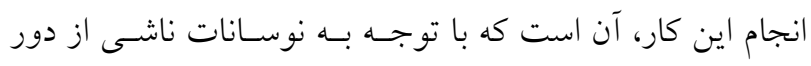

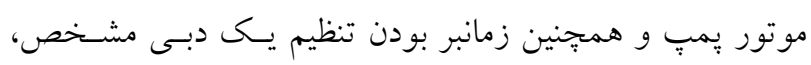

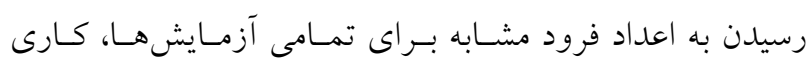

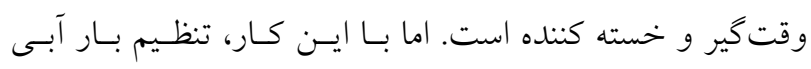
مخزن ذخيره برروى يكى عدد مشخص، كارى آسانتر و دقيقتر

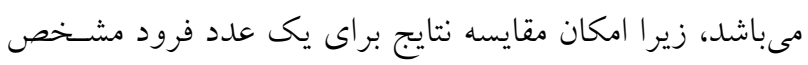

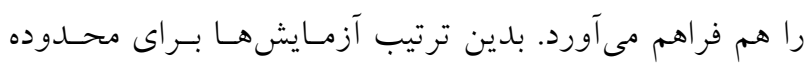

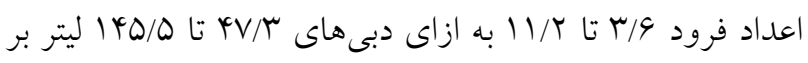
ثانيه در 1 عدد فرود انجام شد.

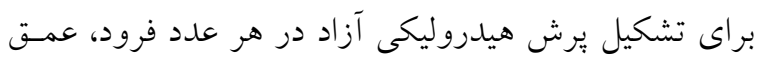

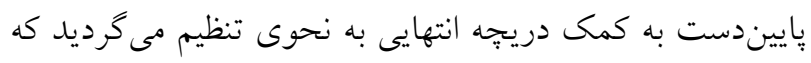

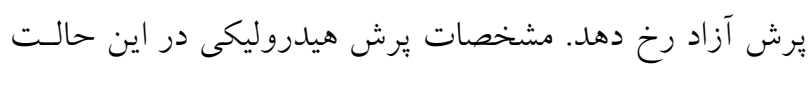


هيدروليكى (L)

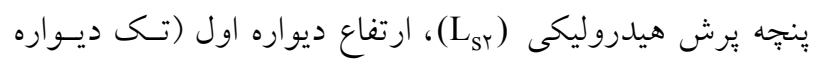

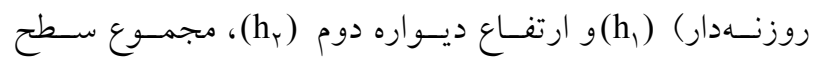

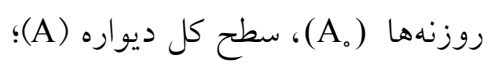

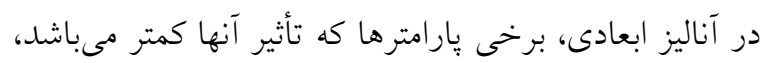

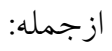

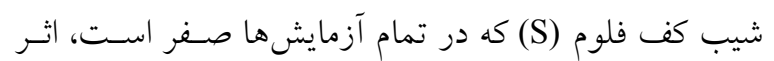

لزوجت كـه بـه شـكل عـدد رينالـدز

مى دهد، بهدليل اين كه جريـان مـتلاطم در تمـام آزمـايشهـا در

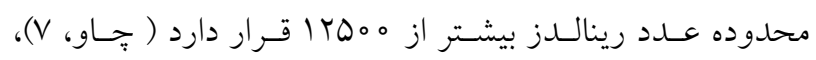

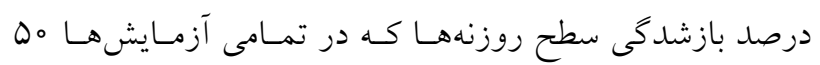

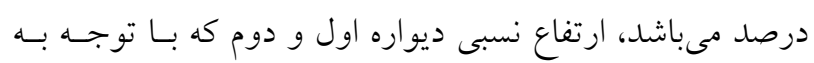

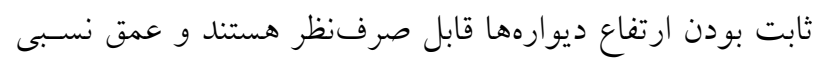

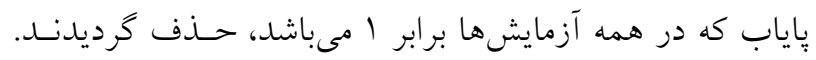

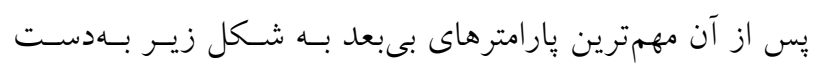

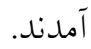

$\mathrm{f}\left(\frac{\mathrm{L}_{\mathrm{S}}}{\mathrm{y}_{1}}, \frac{\mathrm{L}_{\mathrm{Sr}}}{\mathrm{y}_{1}}, \mathrm{Fr}_{1}, \frac{\mathrm{L}_{\mathrm{r}}}{\mathrm{y}_{\mathrm{r}}^{*}}, \frac{\mathrm{y}_{\mathrm{r}}}{\mathrm{y}_{\mathrm{r}}^{*}}\right)=。$

با توجه به اينكه متغيرهاى مهم و مورد نظر عمق نسبى مـزدوج يرش در شـرايط اجبـارى ${ }^{\prime}$ هيدروليكى $)$ رابطه (ه) نوشته شود.

$$
\frac{y_{r}}{y_{r}^{*}}, \frac{L_{r}}{y_{r}^{*}}=f\left(\frac{L_{S 1}}{y_{1}}, \frac{L_{S r}}{y_{1}}, F r_{1}\right)
$$

\section{نتايج و بحث}

تغييرات عمق نسبى ثانويه يرش هيسدروليكى در حضسور دو

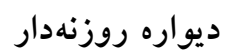

در نمودار شكل (ه) مقادير عمق ثانويه يــرش هيـدروليكى آزاد

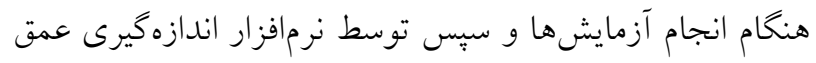

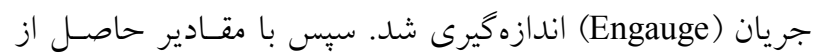

انجام مىشود (r). بس از بررسى نتـايج، و تعيسين بهتـرين زوج

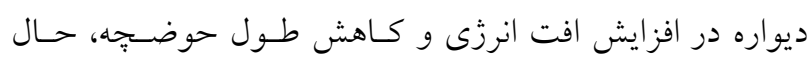

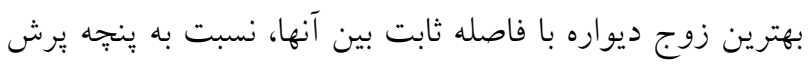

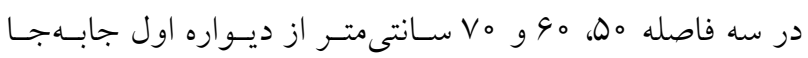

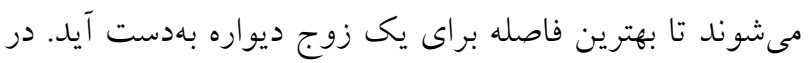

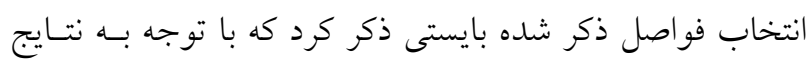

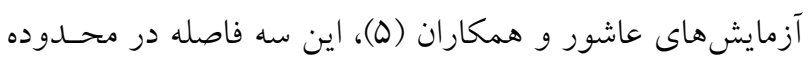

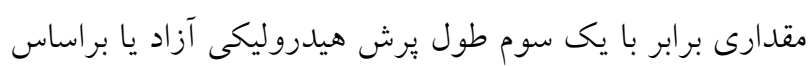

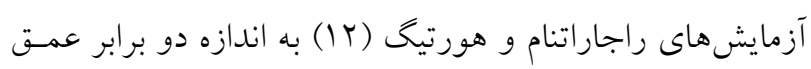

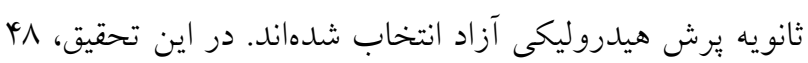

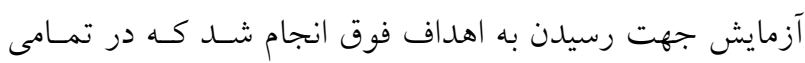

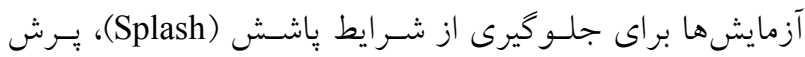
اجبارى بهكونهاى ايجاد كرديد كه ابتدا برش بهصورت بهرت مستغرق

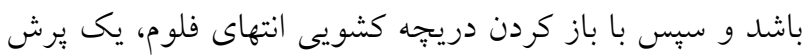
كامل (غيرمستغرق) شكل بخيرد.

\section{آناليز ابعادى و تعيين پِارامترهاى مؤثر}

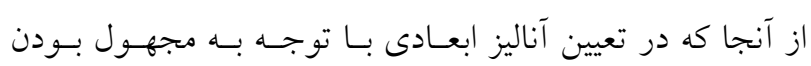

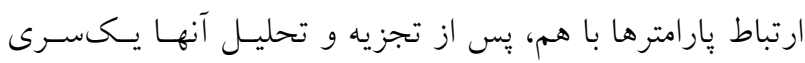

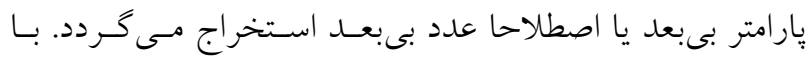

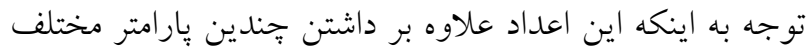

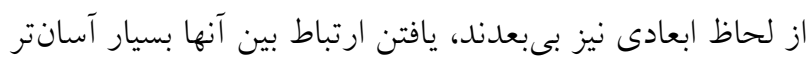

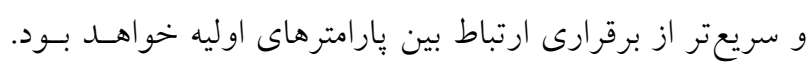

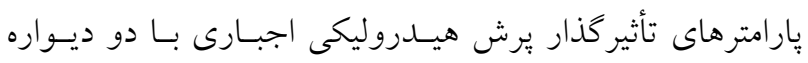

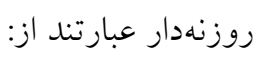
خصوصيات جريان شامل: سرعت ورودىى (V) )، عمق اوليه

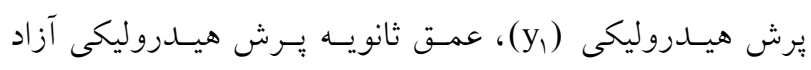

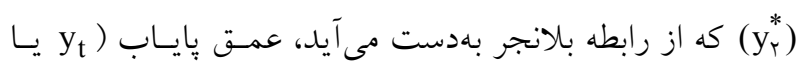

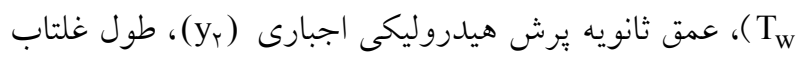

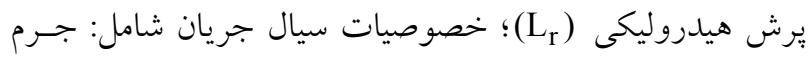
واحد حجم سيال (م)و لزوجت ديناميك (ر)؛ هندسه ديوارهها

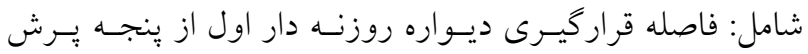




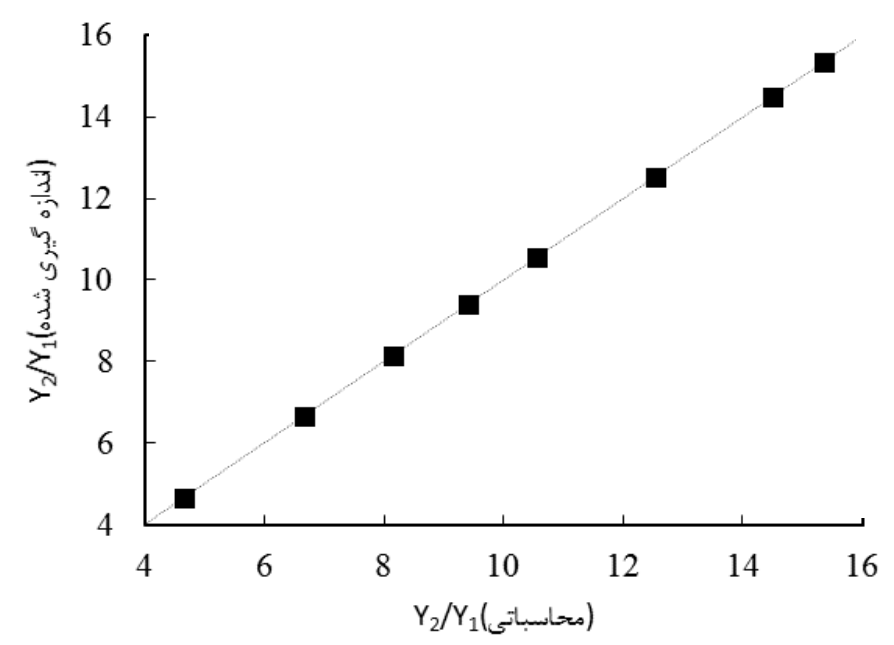

شكل ه. مقايسه عمق ثانويه برش هيدروليكى آزاد اندازهيرى شده در آزمايشكاه با نتايج حاصل از رابطه بلانجر

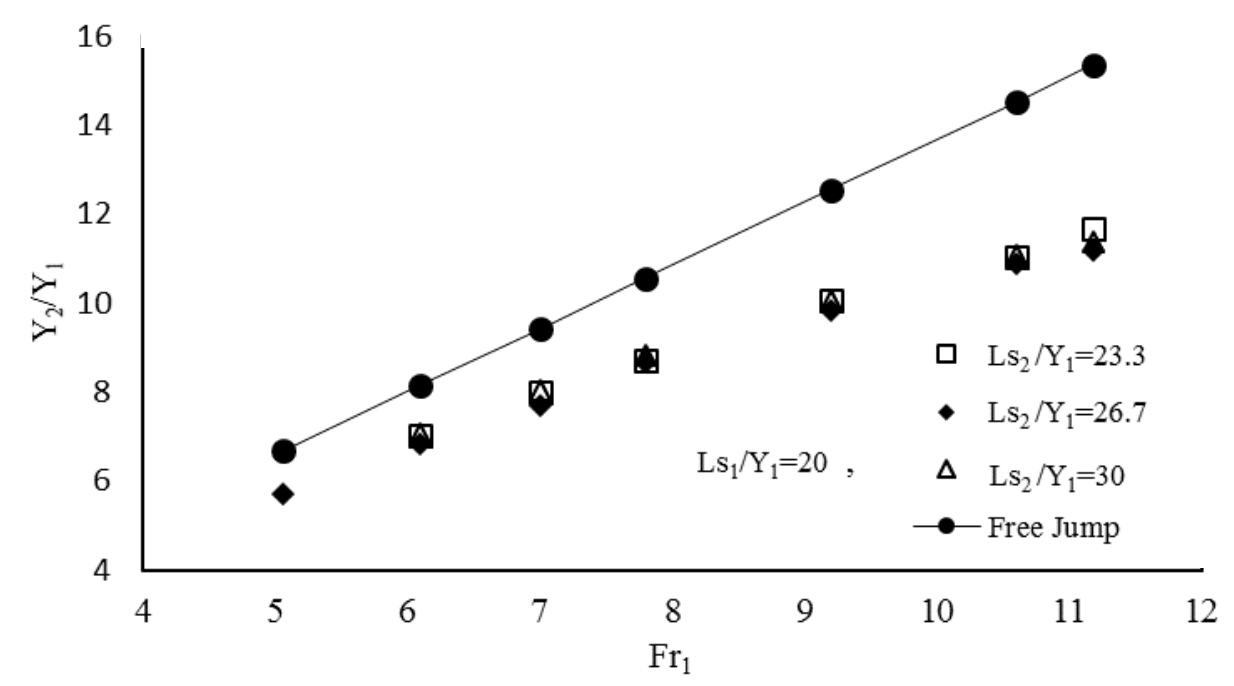

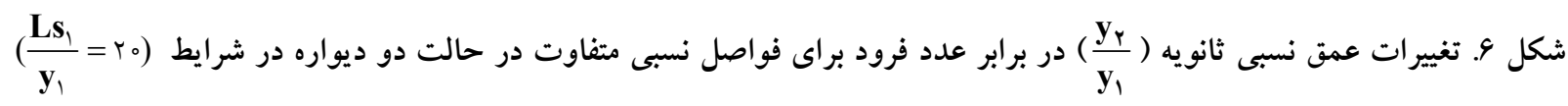

(از ديواره اول قرار مى

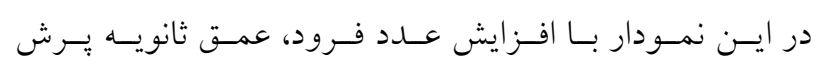

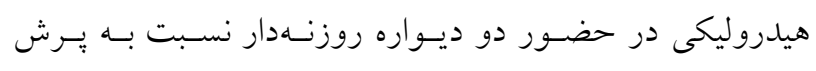

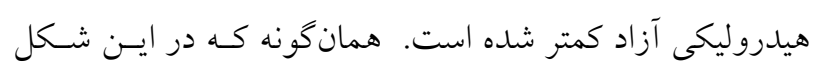

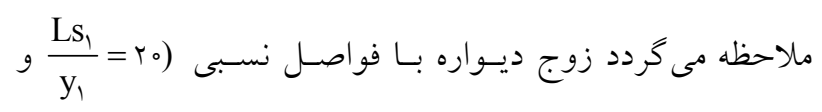
بيشـترين اثـر در كـاهش عمـق نسبى ثانويـهـ را

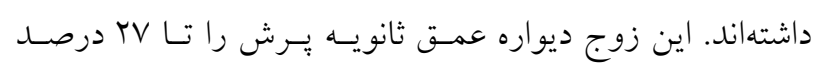

رابطـه (Y) (Belanger Equation) مقايسه و در قالـب نمـودار رسم كرديد. همـانطوركسه در ايسن نمـودار مشـاهده مسىشـود

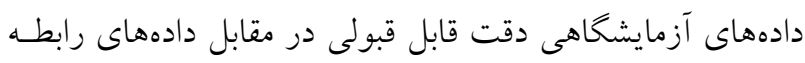
بلانجر دارند.

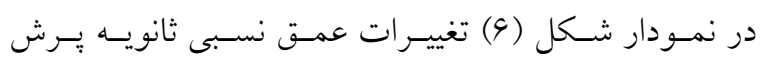

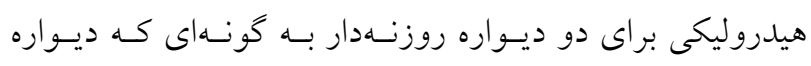
روزنهدار اول در فاصله نسبى (or در فواصـل نسـبى ( 


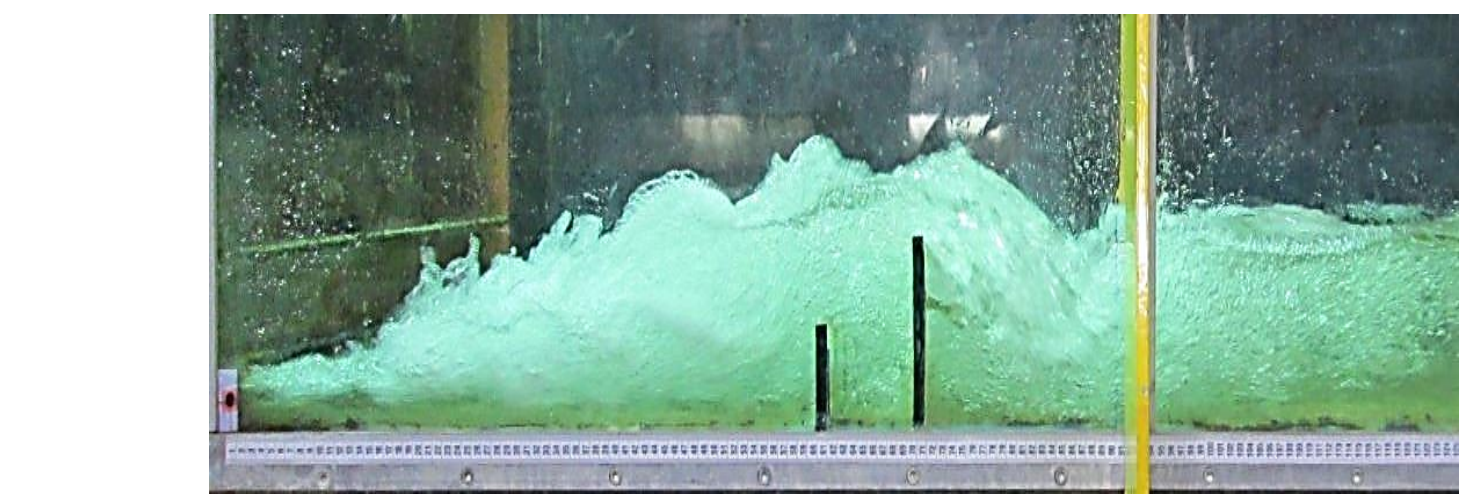

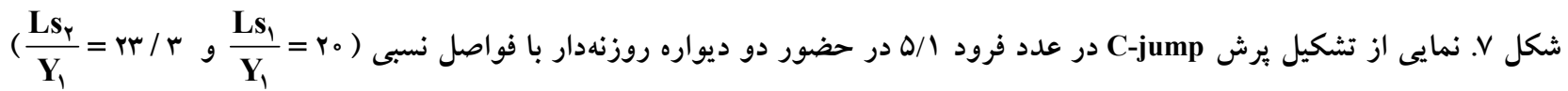

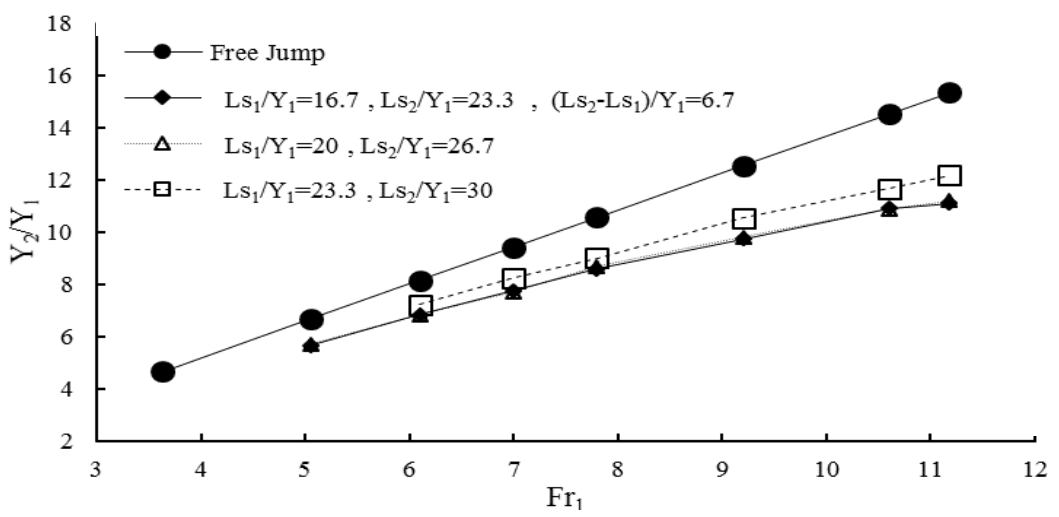

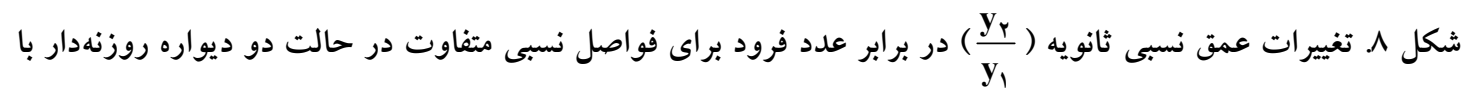

$$
\left(\frac{\mathbf{L} \mathbf{s}_{\Upsilon}-\mathbf{L} \mathbf{s}_{\uparrow}}{\mathbf{y}_{1}}=q / \mathrm{V}\right) \text { شرايط }
$$

نوع C-jump، در حضور دو ديواره روزنهدار را نشان مىدهد. حسال

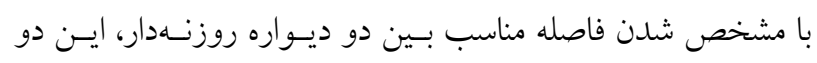
ديواره روزنهدار با فاصله نسبى ثابت يعنى

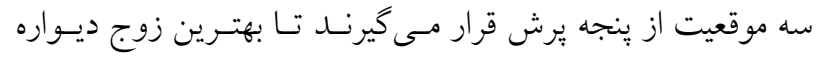

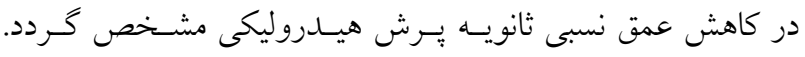

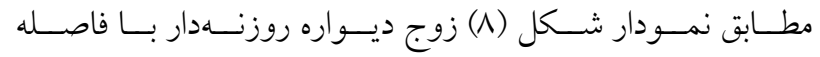
ن. 40 نسبى سانتى متر از ينجه برش جابهجـ $\left(\frac{L_{S 1}}{y_{1}}=r / r\right)$ Vog $\left(\frac{L_{S 1}}{y_{1}}=r o\right)$

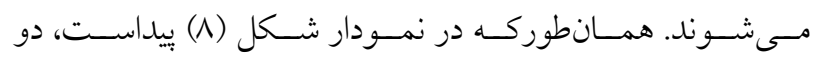
$\left.\frac{\mathrm{Ls}_{1}}{\mathrm{y}_{1}}=19 / \mathrm{V} ، \frac{\mathrm{Ls}_{Y}-\mathrm{Ls}_{1}}{\mathrm{y}_{1}}=9 / \mathrm{V}\right)$ زوج ديواره با فواصـل نسبـ
نسبت به يرش هيدروليكى آزاد كاهش مىدهند. با دقت در نمـودار

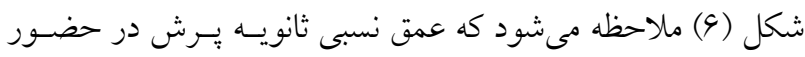

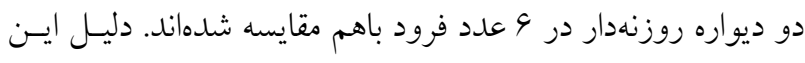

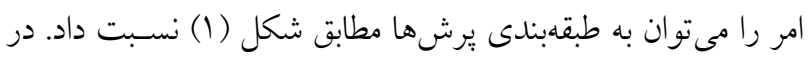

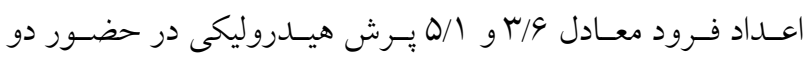

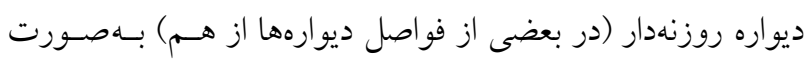

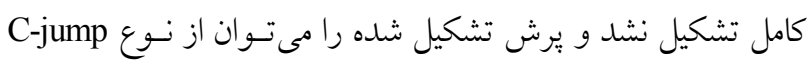

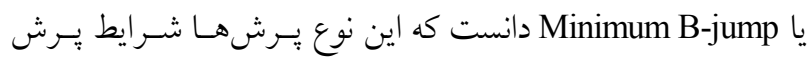

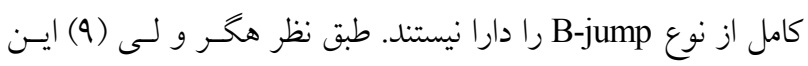

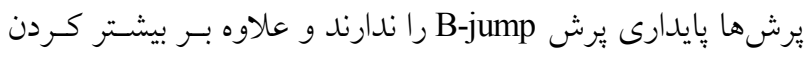

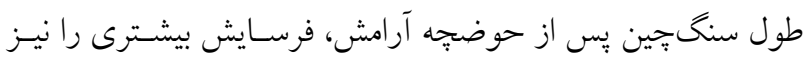

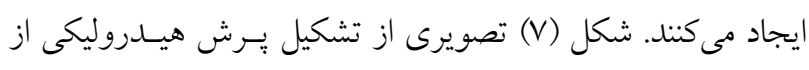


جدول ا. درصد كاهش عمق نسبى ثانويه نسبت به برش هيدروليكى آزاد براى نمودار شكل (^)

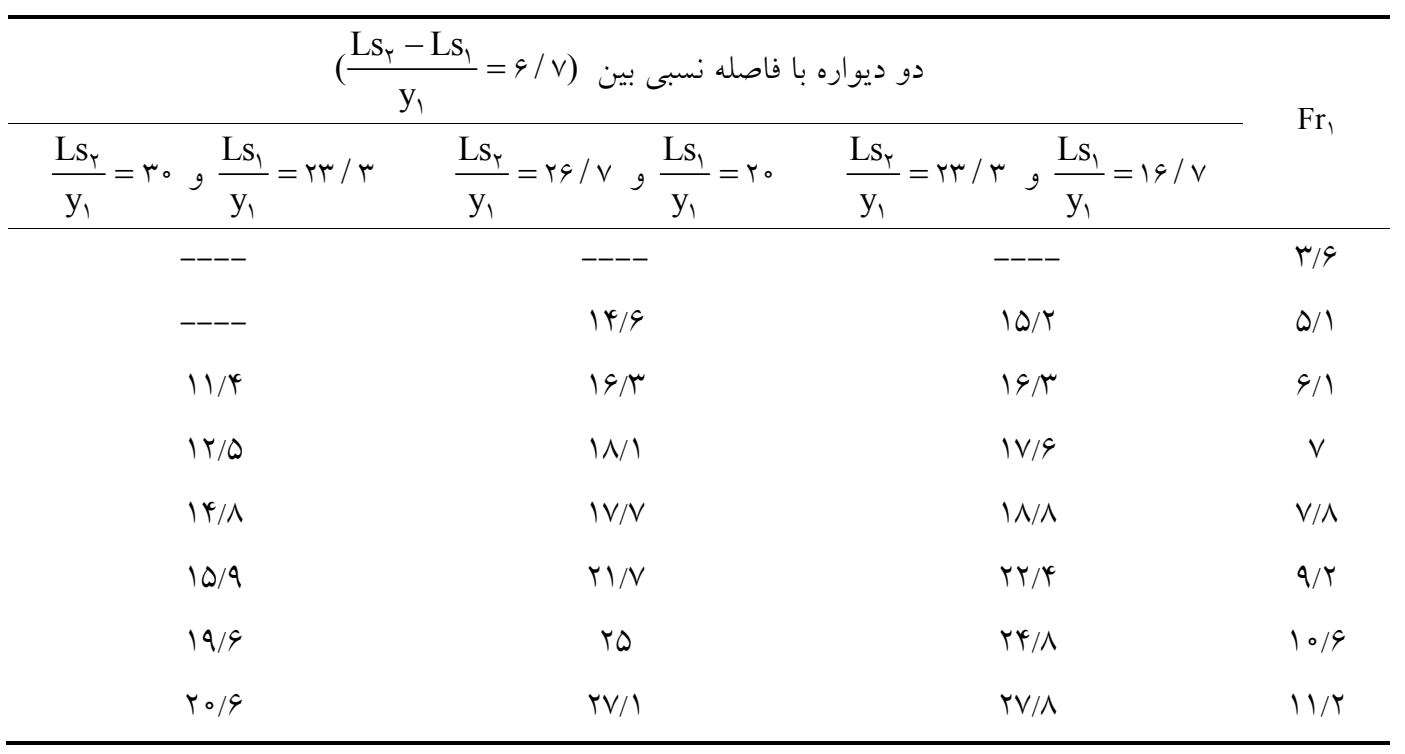

خروجى از روزنههاى ديواره اول به قسمت بيوسته ديـواره دوم

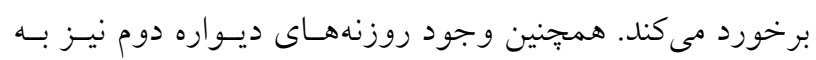

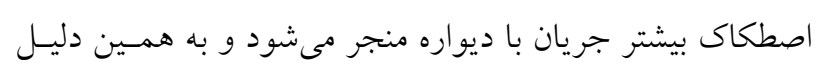

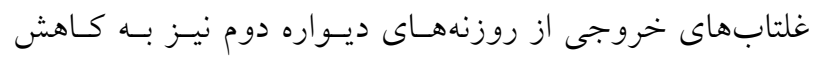
بيشتر عمق ثانويه كمك مى كنند.

تغييرات طول غلتـاب در حوضسجه آرامسش در حضـور دو ديواره روزنهدار

نمودار شكل (9) تغييرات طول نسبى غلتاب در برابر عدد فرود، در حضور دو ديواره روزنهدار در شرايطى كه ديـواره روزنسهدار اول در فاصله نسبى (r) $\left(\frac{\mathrm{Ls}_{\mathrm{Y}}-\mathrm{Ls} s_{1}}{\mathrm{y}_{1}}=10\right),\left(\frac{\mathrm{Ls}_{\mathrm{Y}}-\mathrm{Ls}_{1}}{\mathrm{y}_{1}}=9 / \mathrm{V}\right) ،\left(\frac{\mathrm{Ls}_{\mathrm{Y}}-\mathrm{Ls} s_{1}}{\mathrm{y}_{1}}=r / r\right)$ از ديواره اول باشد را نشان مىدهد. زوج ديواره با فواصل نسبى لإل از پنجه يرش، طول غلتـاب را تـا

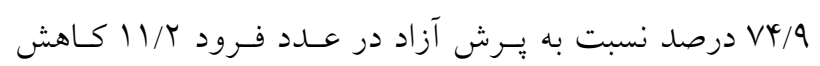

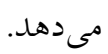
با معلوم شدن بهترين زوج ديواره در كاهش طـول غلتـاب، مطابق تئورى آزمايش، اين زوج ديواره را درحالى كه فاصله بـين رون دين
, $\left.\frac{L s_{1}}{y_{1}}=r_{0} \quad ، \frac{L s_{Y_{1}}-L s_{1}}{y_{1}}=q / v\right) \quad, \quad\left(\frac{L s_{Y}}{y_{1}}=r r / r \quad g\right.$

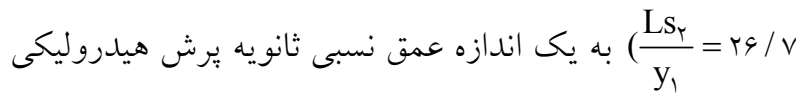

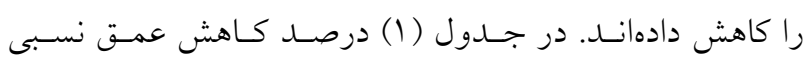

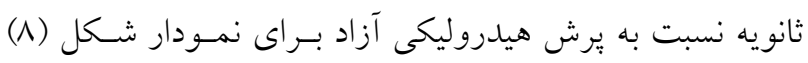

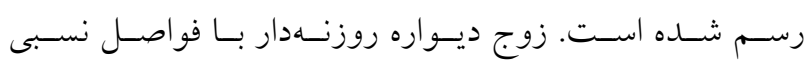

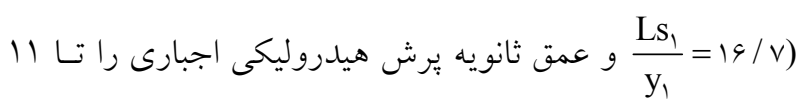
درصد بيشتر از دو ديـواره وييوسـته مطـابق نتـايج آزمـايشهـاى

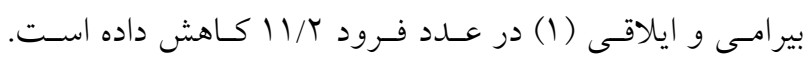

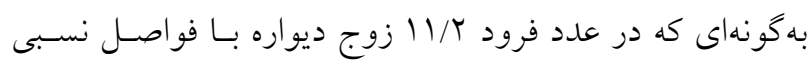

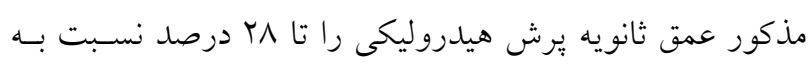

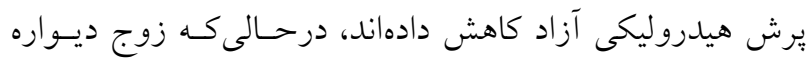

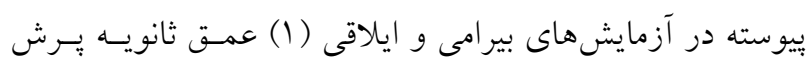

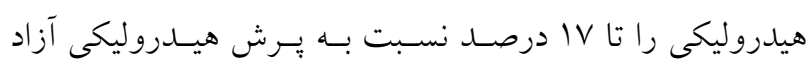

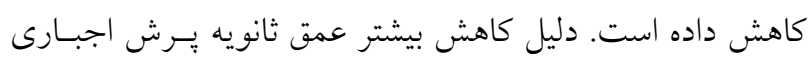

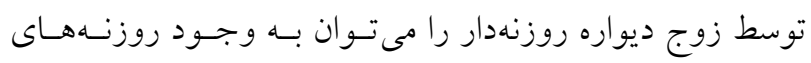

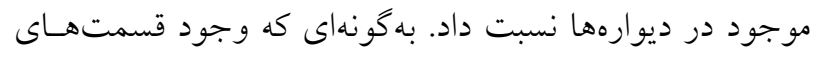
روزنهدار و ييوسته تعبيه شده در ديوارهها باعـث كـاهش بيشـتر

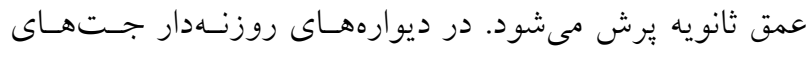




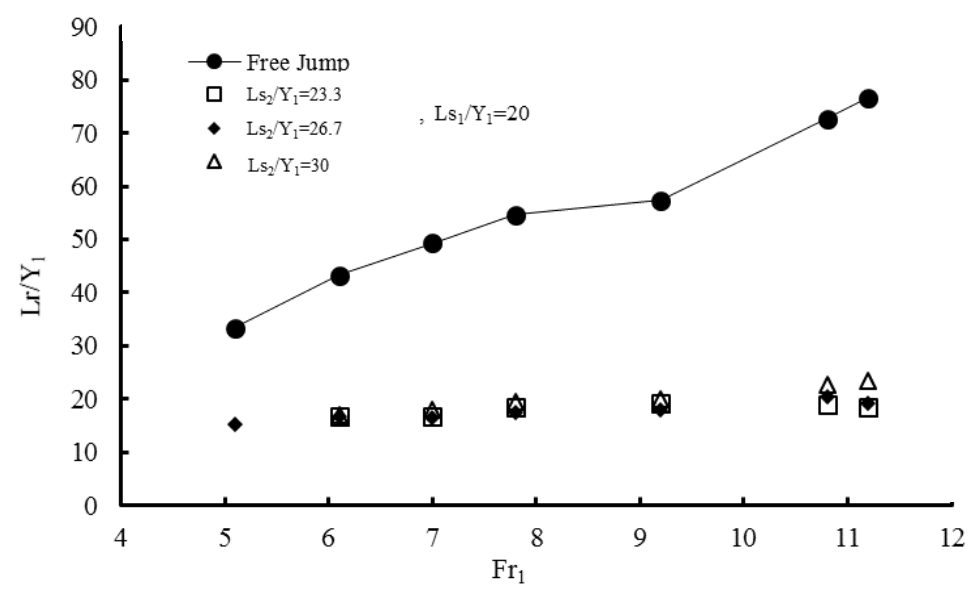

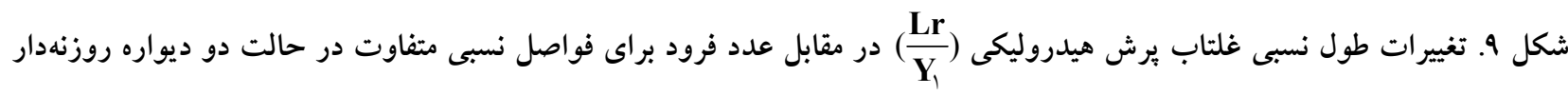
$\left(\frac{\mathbf{L} \mathbf{s}_{1}}{\mathbf{y}_{1}}=r_{0}\right)$ با شرائ

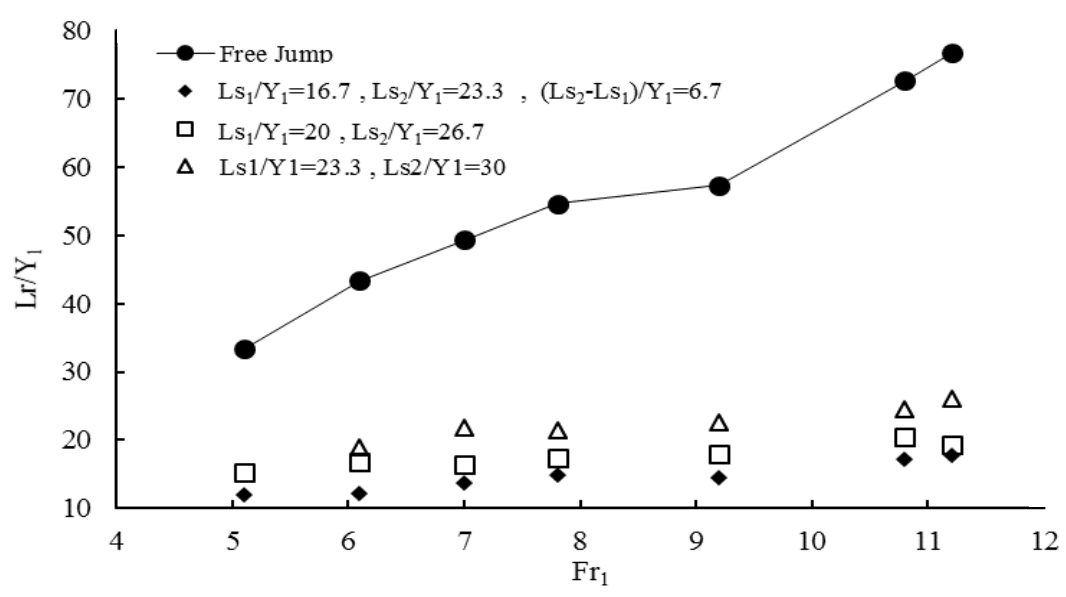

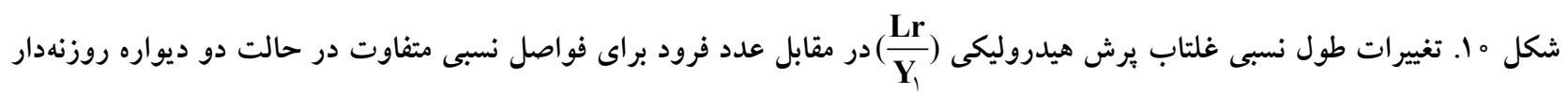

$$
\left(\frac{\mathbf{L} \mathbf{s}_{\curlyvee}-\mathbf{L} \mathbf{s}_{1}}{\mathbf{y}_{\backslash}}=\right.\text { ب/V) با شرايط }
$$

فواصل نسبى VG/9 درصد نسبت به يرش آزاد در عدد فرود ال آ كاهش داده

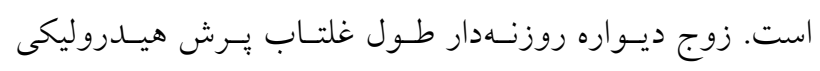

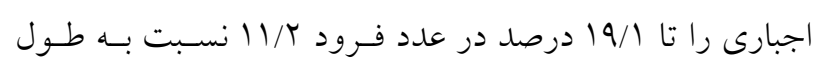

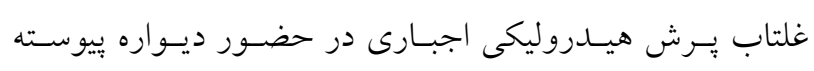

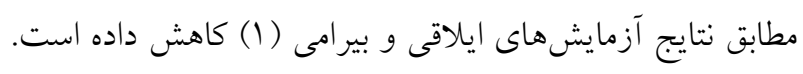

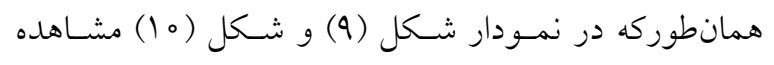

آنها ثابت مىباشد، نسبت به ينجه يرش جابجا كرده تـا بهترين

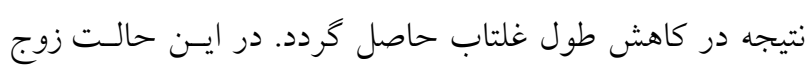
Dيــواره بــا فواصـل نسـبى $)$ سانتى مترى $\left(\frac{L s_{1}}{y_{1}}=r / r\right) V_{0} g\left(\frac{L s_{1}}{y_{1}}=r_{0}\right) 9_{0} ،\left(\frac{L s_{1}}{y_{1}}=19 / V\right)$

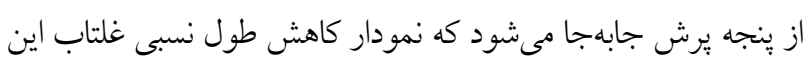

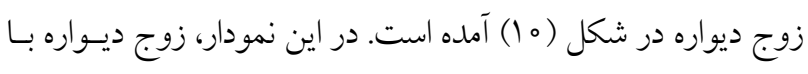




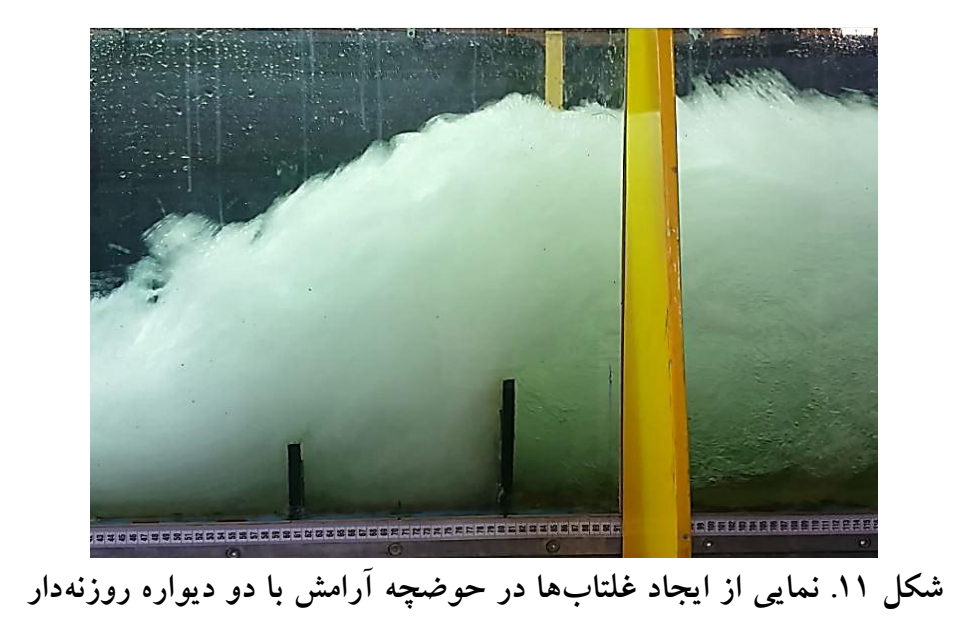

روزنهدار تأثير بسيار مهمى در ايجاد يرش هيدروليكى، كنتـرل و

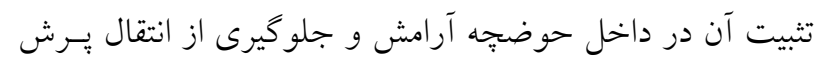

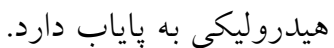

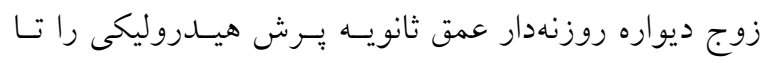
TV/VD

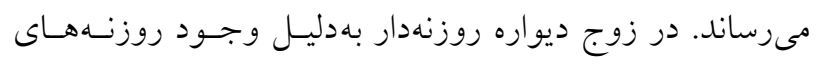

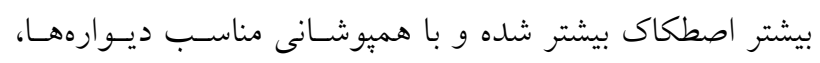

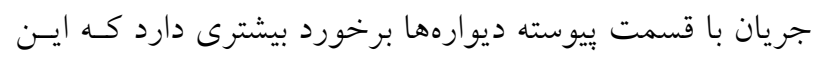

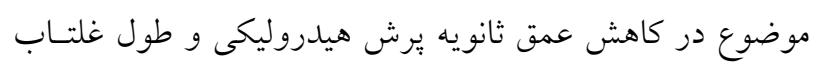

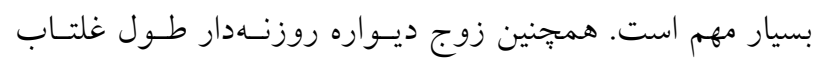

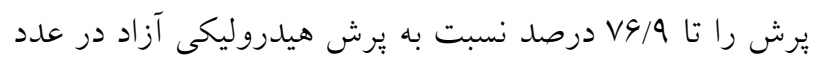

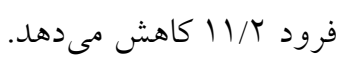

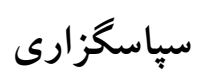

اين تحقيق با كمك مالى از محل بزوهانـه نويسـنده دوم تـأمين

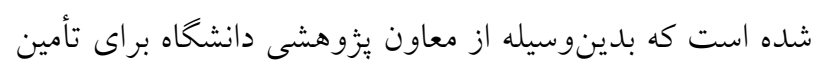

$$
\text { يزوهانه تشكر و قدردانى مىشود. }
$$

مىشود با افزايش عدد فرود كاهش طول نسبى غلتاب نسـبت بـهـ

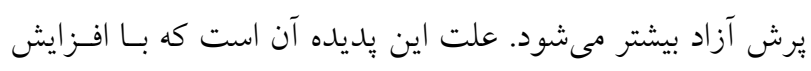

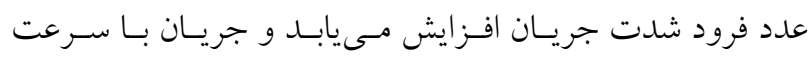

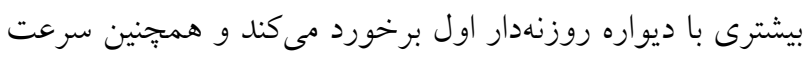

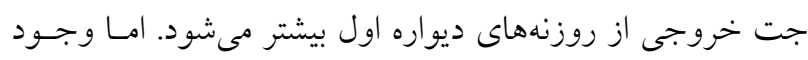

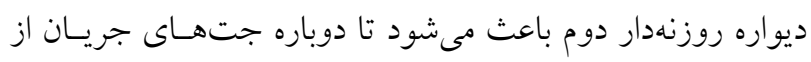

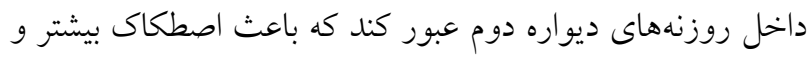

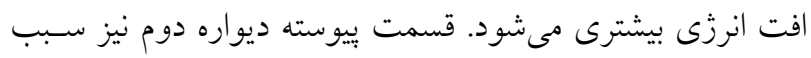

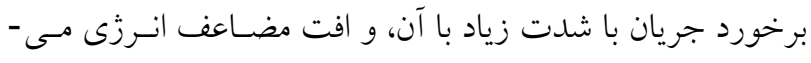

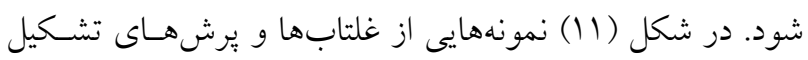
شــه در حضـور دو ديـواره روزنـهدار نشـان داده شـــه اسـت.

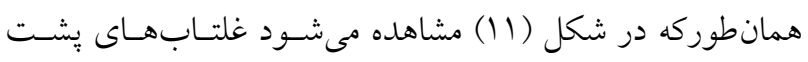

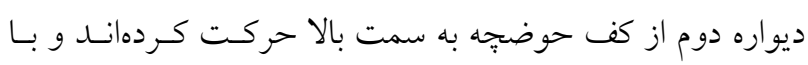

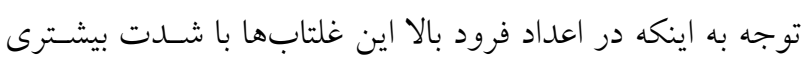

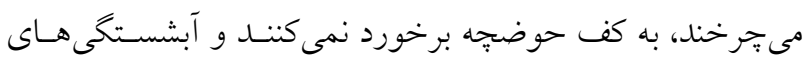
شديد در بايين دست حوضجه آرامش ايجاد نمى شوده.

$$
\text { نتيجه گيرى }
$$

آزمايشهـاى انجـام شـــه نشـان داد كـهـ اسـتفاده از دو ديـواره

منابع مورد استفاده

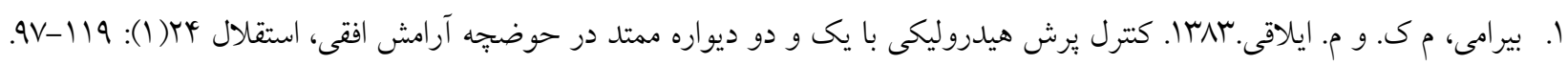




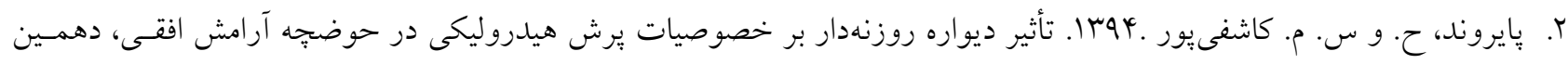

$$
\begin{aligned}
& \text { سمينار بين المللى مهندسى رودخانه، دانشخاه شهيد بِمران اهواز. }
\end{aligned}
$$

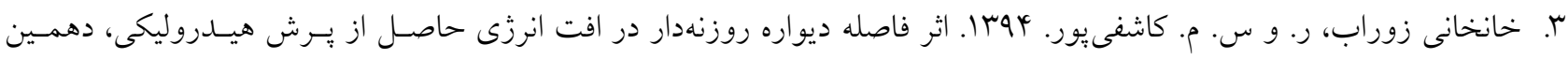

$$
\begin{aligned}
& \text { سمينار بين المللى مهندسى رودخانه، دانشخاه شهيد جِمران اهواز. }
\end{aligned}
$$

4. Ashour, M. A. T. Sayed and S. El-Attar. 2015. Impact of Curved Shaped Energy Dissipaters Downstream Diversion Head Structures on the Dissolved Oxygen Content in Irrigation Canals \& Enhancement of Irrigation Water Quality. IJSRT 2(2):14-26.

5. Behrouzi-Rad, R. M., H. R. Fathi-Moghadam and A. Alikhani. 2013. Generation of hydraulic jump with sill, A Sci. J. of the Regional Museum of Carinthia. 20(2): 300-309.

6. Chow, V. T. 1973. Open Channel Hydraulic, McGraw-Hill, New York.

7. Hager, W. H. Bremen, R. And Kawagoshi, N. 1990. Classical hydraulic jump: length of roller, J. of Hydraulic Res. 28(5): 591-608.

8. Hager, W. H. and D. Li. 1992. Sill-controlled energy dissipator. J. of Hydraulic Res. 30(2): 165-181.

9. Helal. E. Y., T. H. Nassralla and A. A. Abdelaziz. 2013. Minimizing of scour downstream hydraulic structures using sills. IJCSE 3(3): 591-602.

10. Lin, C., J. Yen and C. Tsai. 2002. Influence of sluice gate contraction coefficient on distinguishing condition. J. of Irrig. and Drainage Eng. 128(4): 249-252.

11. Rajaratnam, N. and K. Hurtig. 2000. Screen-Type Energy Dissipator for Hydraulic Structures. J. of Hydraulic Eng. 126(4): 310-312.

12. Rand, W. 1965. Flow over a vertical sill in an open channel. J. of Hydraulic Division, ASCE 9:97-122.

13. Rand, W. 1967. Flow over a dentaited sill in an open channel. J. of Hydraulic Division, ASCE 9:135-153.

14. Safranez, K. 1929. Untersuchungen ueber der wechselsprung, Bauingenieur 649-668.

15. Ohtsu, I., Y. Yasuda and H. Hashiba. 1990. Drag on vertical sill of forced jump. J. of Hydraulic Division, ASCE 122: 465-469.

16. - Ohtsu, I., Yasuda, Y. and Hashiba, H., 1990, Drag on vertical sill of forced jump. J. of Hydraulic Division, ASCE 122: 465-469. 


\title{
A laboratory Study on the Effect of Perforated Sills in Stilling Basin on the Secondary Depth and Length of the Roller of the Hydraulic Jump
}

\author{
R. Khankhani Zorab* and S. M. Kashefipour ${ }^{1}$
}

(Received: Nov. 27-2016; Accepted: May 6-2017)

\begin{abstract}
The purpose of this study was to evaluate two perforated sills in the stilling basin and their impact on characteristics of the hydraulic jump, such as the length of the roller of hydraulic jump, decrease in the secondary depth of the hydraulic jump, and the required tailwater depth. Also, the optimal distance of two perforated sills from the beginning of the stilling basin with a fixed height for the perforated sill and ratios of the opening of holes equal to $50 \%$ were determined. The experiments were carried out in the form of 48 tests for different discharges in the range of 47 to 145 lit/s and for Froude numbers in range of 3.6 to 11.2. The results of the experiments on two perforated sills showed that they could only reduce the length of the roller of the hydraulic jump to an acceptable level, with the distance between them providing the conditions to create a stable jump; also, the length of roller of jump was not decreased by reducing the distance between the sills. Also, they decreased the secondary depth of the forced hydraulic jump up to $27.8 \%$, which was less than the secondary depth of the free hydraulic jump; the length of roller was up to $76.9 \%$ less than the length of the roller of the free hydraulic jump for the Froude number of 11.2.
\end{abstract}

Keywords: Perforated sill, Hydraulic jump, Stilling basin, length of roller, Secondary depth of force hydraulic jump.

1. Faculty of Water Sci. Eng., Shahid Chamran Univ. of Ahvaz, Ahvaz. Iran.

*: Corresponding Author, Email: reza_khankhani@yahoo.com 